\title{
A Review on Historical Aspects of Critical Pedagogy
}

\author{
Raj Kishor Singh \\ $\mathrm{PhD}$ \\ Central Department of English \\ Tribhuvan University \\ Kirtipur, Nepal \\ drrksnp@gmail.com
}

\begin{abstract}
This paper makes a review of inventory and application of critical pedagogy in education sector, in particular, and also in general practices of critical thinking, skepticism, decision making process, etc. Critical pedagogy as a concept originated and developed in academia, for development of critical mind of learners. Education broadens the students' views of reality. Education is transformative, bringing all kinds of changes in human mind, as well as in the society and the nation. Education makes students critical and skeptical on the issues which are frequent in their daily life. Therefore, all kinds of social, cultural, economical and political issues are solved by critical mind of the learners. Education must be democratic in nature and system. People in power make education system in their own favour, dominating the powerless people. Therefore, education is political. Those who participate in critical pedagogy resist the constraints that those in power impose on them. Critical pedagogy can be applied in all faculties and subjects like music, economics, mathematics, sociology, political science, English language teaching, English literature teaching, and so on. Teachers also must be qualified with the critical pedagogy approach. They must be confident with the knowledge and skills for applying Freire's methods of teaching effectively in the classroom. They must
\end{abstract}


be critical thinkers, self-reflective, culturally conscious for the pedagogical situation to enhance students' understanding of the world.

The major purpose of this review is to point out the effectiveness of critical pedagogy in education and in general. After teachers' role in critical pedagogy, knowledge of the language and of the world, consciousness or 'conscientization', power resistance, value judgments, perception of reality and truth, empowerment, transformation, decision making skills, critical thinking, skepticism, negotiation, problem posing and solving, and many other aspects of learning in critical pedagogy are explained in this review paper.

Keywords: Critical Pedagogy, Conscientization, Power Resistance, Value Judgments, Empowerment, Critical Thinking, Skepticism, Negotiation

Introduction

The Brazilian educationalist Paulo Freire founded and contributed to both the theoretical and practical development of his concept critical pedagogy. He discussed about critical consciousness, conscientizacao, a consciousness beyond understanding which leads to action (Freire, 1970). According to Kincheloe, "Emerging from Paulo Freire's work in poverty stricken northeastern Brazil in the 1960 s, critical pedagogy amalgamated liberation theological ethics and the critical theory of the Frankfurt School in Germany with the progressive impulses in education..." (Kincheloe, 2007). Michael Apple, Henry Giroux, Donald Macedo, Peter McLaren and Ira Shor have contributed to enrich Freire's concept of critical pedagogy.

McLaren defines the term as, critical pedagogy is a way of thinking about, negotiating, and transforming the relationship among classroom teaching, the production of knowledge, the institutional structure of the school, and the social and material relations of 
the wider community, society, and, nation state (McLaren, 1998). Shor describes critical thinking as "Habits of thought, reading, writing, and speaking which go beneath surface meaning, ...” (Shor in Rexhepi \& Alberto Torress, 2011).

Critical pedagogy aims at investigating, questioning and changing the relationship among different factors in the learning experience. These factors include classroom teaching, the structure of the school, and the social relations with the community. This imposes a great task on the critical pedagogue as he has to take into account a wide range of social and educational variables in his work.

Development of the mind for critical thinking and reasoning is the main focus area of critical pedagogy. Critical consciousness or 'conscientization' is the major concern in Paulo Freire's thought (Freire, 1974). Traditional education system does not meet the demands of the present world, because this system keeps learners' mind vacant; they are unable to face the challenges in real life. Education system determines the economical, social, political, and cultural system of a nation. It depends on the fact how the students are prepared for the daily life, which, in turn, determines the development of the society, and the nation as well.

Freire proposes critical pedagogy with the aim of developing critical thinking of learners, posing a problem so that they can discern, think about, and act on it. They can find out solutions. Critical pedagogues argue that literary theories are the foundations of this theory. Mainly Marxist theory has a great influence upon critical pedagogy. Theoretical concept is that critical pedagogy develops critical thinking among learners; critical thinking raises critical consciousness among them; and this consciousness enhances critical literacy. All these are necessary for people to face challenges in the world. Teachers or students pose questions or problems. Teachers or students are both involved in discussion/interactions. They develop skills of critical thinking from this process and, meanwhile, solutions are discovered. Critical consciousness brings up transformation in the society, which is necessary 
for the entire development of the community. Economic, political, sociological revolution is possible from the approach critical pedagogy.

\section{Vedic Age of Critical Pedagogy}

Critical pedagogy was practiced in past in Gurukula education system with many other terminologies and contexts. The educational institutions, Gurukulas, of Vedic age were situated in remote areas, mostly in forests in peaceful location. Religious practices and discipline between teacher and students created some boundaries over open and democratic practices of critical pedagogy in Gurukulas. Gurukula was the place of learning where Guru (teacher) was God for the students. There were strict rules and regulations for students to follow in these Gurukulas. Students were under strict discipline. They used to obey the order of their teacher without any questions and objections. They used to sit down on the floor while their teacher used to sit on the terrace. They were humble before Guru and also inside the Gurukulas. They should possess the quality of charity.

The teacher had a great role to create confidence among the students. Atharvaveda says, "the teacher, by teaching noble code of conduct, improves the control upon the sense organs of the students" ( Atharvaveda 11-5-17). Again Atharvaveda says, "teacher behaves like Yamadeva as the symbol of rules, regulation and justice, he behaves like Varunadeva as he is impartial in his nature and also he behaves like Somadeva as he is the giver of happiness and pleasure by providing the Ausadhi to eradicate the diseases like ignorance" (Atharvaveda 11-5-14). In Upanisadic period, students were tremendously efficient to know Sastric knowledge.

Some institutionalized methods of teaching in Gurukulas of Vedic age were: Oral transmission of Knowledge, Debate and Discussion, Seminars, Debating circles and Academy (Parishad), and Conferences (Vidvatsabha). 
The whole teaching-learning system of Vedic age was categorized into two levels: citing and chanting lines of the Vedamantra loudly by the teacher and memorizing these lines by the students. These memorized lines were re-presented by the students before the teacher. Teaching was mainly categorized into five different stages which were implemented in Vedic education system: Acceptance of Veda, Discussion, Practice, Chanting, and Distribution of knowledge. There were three different stages of learning to achieve knowledge: Listening (Sravanam), Memorizing ( Mananam), and Practicing (Nididhyasanam) (Swain, 2016).

A student used to listen to the lesson of the teacher carefully. He used to memorize the lesson what was taught to him by the teacher, and, at the end, he used to re-present before the teacher. This was the regular practice of learning at Gurukula.

In Vedic age, the lesson related to Upanisad was taught to the students through the logical method (Tarkavidhi). Particularly the philosophical discussion between the teacher and the student was made through the logical method as per the guidance of Nyayasastra. According to Nyayasastra , Pararthanumana consists of five elements, such as - Pratijña Roughly a Proposition, Hetu - Reason, Udaharana- Example, Upanaya - Confirmatory Sentence, and Nigamana- Conclusion (Swain, 2016).

Such type of reasoning method was adopted in Vedic system of education. This logical method was important for philosophical and spiritual lessons taught by the teacher. In Upanisadic discourses, the logical method was highly and significantly adopted. We can observe this method in Kathopanisad during the discussion between Yama and Nacikata.

Question-answer method (Prasnottaravidhi) was the process of teaching and learning in Vedic education system. This was a good method for clarifying doubts. Questions were raised by the students and answers were given by the teacher. In Vedic education system, raising questions to the teacher by the students was considered to be best practices. Skepticism was a good thing. Acquisition of the knowledge was only possible by questions 
and answers. Such method of learning was also found in Yajurveda. In the mantra of Yajurveda, one part of the mantra denotes question raised by student and another part of the mantra denotes its answer given by the teacher. (Swain, 2016)

In Upanisadic education, they used dialogue method (Sambadavidhi). They used to give more emphasis on Brahmavidya. Knowledge was a sacred in all aspects of human life. The whole Upanisadic knowledge was transmitted through dialogue method between student and teacher.

The Prashna Upanishad was used to a great length in Vedic age. Prashna means "question". In Prashna Upanishad, there are six students who ask questions and their teacher (Guru) answer these questions. For the same reason, it was named as the Prashna Upanishad. Among the top ten Upanishads, three are from the Atharva Veda. They are Mundaka, Maandukya and Prashna Upanishads. Upanishad literally means "to sit near" and listen to the truth being expounded. That is precisely what happens in the Upanishad. (Gurubhaktananda, 2017)

Critical thinking, creative thinking, critical approaches, critical pedagogy, etc. were practiced in different forms in Vedic age. Teachers were wise and intellectual and also very skillful in pedagogy. Students were encouraged for questions and answers to develop their critical mind and skills. In the present education system, we have lost this heritage and naturally we have to follow the hierarchy which demands critical pedagogy.

\section{Modern Age of Critical Pedagogy}

Critical pedagogy is a widely used term in language teaching and also in general education. Critical pedagogy is very commonly linked with the problem posing model of education which was first espoused by Paulo Freire in 1973, in his book "Pedagogy of the Oppressed". Freire's major concern was to challenge the politics of education and, by 
extension, society, in the classroom (Aliakbari \& Faraji, 2011). His model was just a response to the traditional and unfair social politics that propagates the banking model of education. This banking model of education characterises the students' minds as tabula rasa and the teacher's mind as a source of knowledge. The teacher is source of truth and reality. He introduces and prescribes ideas as 'truth' and 'reality' in their minds. Critical pedagogy challenges this depositing of unquestioned information set in the students' minds by teachers.

Critical pedagogy as teaching approach believes that "knowledge emerges only through invention and reinvention, through the restless, impatient, continuing, hopeful inquiry human beings pursue in the world, with the world, and with each other" ((Aliakbari \& Faraji, 2011, p. 72). In Critical pedagogy model, teachers are disempowered but students are empowered with all kinds of privileges and tools needed to discover invisible codes that determine power relations on their own, challenging the question of silence, and reconstructing these codes (Aliakbari \& Faraji, 2011; Crookes, 2010).

Theory of critical pedagogy emphasizes on the fact that the teacher trusts and invests in the learner's ability to reason and engage in independent thought. In the present teaching system teacher has assumption that it is the student whose trust needs to be gained. Critical pedagogy is a more democratic approach to the power dynamics in the classroom between the teacher and the student. The main aim of Freirean critical pedagogy is to liberate the oppressed (in this case, the students) from the ideological control of the oppressors (in this case, society) by working together.

Freire says, "Teachers and students (leadership and people), co-intent on reality, are both Subjects, not only in the task of unveiling that reality, and thereby coming to know it critically, but in the task of recreating that knowledge" (p. 69). In this way, critical pedagogy nurtures "an uncolonized imagination" (Crookes, 2010, p. 334). Students can thus better read and negotiate the world (Van Duzer \& Florez, 1999; Wilson, 2014). Freire names this 
achievement 'critical consciousness'. This is also called the foundation of critical literacy. The teacher uses the components of critical pedagogy in the classroom context and facilitates learning.

Teacher develops critical thinking by presenting a situation or a case or a problem to the students so that they can discern, think about, and act on it. This model suggests that the life situation of the learners should be the primary content of curriculum. Dialogue between teacher and students or among the students is process of getting solution. Dialogue usually forms the context of the educational situation.

Teacher participates in the dialogue. He or she contributes the students to identify the subjects which are problematic. They do not solve the problems. They inspired the students to think over those problems and bring out some solutions. Teacher is an incentive for a process of collaboratively constructed knowledge. Students question ideologies, cultural practices, rituals, politics, views, laws, rules, ethics, etc. which are considered to be oppressive, and teacher encourages collective and individual responses to the issues for practical application in their life.

\section{Educational Interests in Critical Pedagogy}

For nearly a half century, educationists have been showing interest in development of critical thinking dispositions among students. Education must be managed with teaching knowledge of content and civic skills. It is not good to teach several skills but their implication in real life practice. We cannot just wait and see what the learners will do in practice. Implementation of such skills from very beginning of learning can be possible through a critical pedagogy. Education through critical pedagogy aims at informing the students about political, cultural, economic, environmental, and social setbacks. It inspires to think of a solution to tackle the problems that come to them and transform the situation to 
everybody's benefit. Critical pedagogy provides them all the skills and ground for application for effective critical thinking.

Critical pedagogy criticizes the conservative discourse on education. It mainly concerns with innovative and critical environment of schools with cultural production and struggle of the students. The school environment provides teacher and students' involvement for students' resistance, consciousness, critical and skillful mind for solving any issues and problems.

In traditional approaches, teachers' interventions are compulsory with a belief that students learn anything in the classroom only with the interventions. Good pedagogical interventions will most effectively facilitate learners' assimilation of new systemic knowledge into known knowledge structure but critical pedagogy or socio-culturally informed studies offer much different recommendations for improving classroom practice.

Critical pedagogy values learners' culture and requirements of learning. The course book developers are more sensitive on the learners' cultural context. It has the added value of enabling learners to think about the different aspects of their culture and find ways to transform the society where necessary (Akbari, 2008).

Canagarajah (2005) remarks that critical pedagogy is a way of doing, learning and teaching, or a practice motivated by a distinct attitude towards classroom and society. Pennycook (1990) suggests that the nature of second language education, however, requires us to understand our educational practice in broader social, cultural, and political terms. In his opinion, we should turn to critical pedagogy to extend our conception of what we are doing as language teachers. Critical pedagogues seek social justice and change through education. The promoters of this theory argue against the dominance of a certain group of people in decision making and policy setting. 
Akbari (2008) says that decision makers in power are responsible to design and implement educational systems in a country. Naturally, their ideas and values get accepted and promoted while the values and ideas of others are not given voice. These ideas and values of others become significant in critical pedagogy. These are given place in education.

Simon suggests that "the first premise of any form of critical pedagogy is that the knowledge claims are interested and are modes of intelligibility grounded in the struggles, tensions, and inequalities that mark history's bequest to the present" (as cited in Pennycook, 1990). Therefore, it is remarkably important for teachers to bring it to people's awareness and activate them of their rights and abilities as social agents who can bring about change. Education through critical pedagogy is believed to bring about transformation.

In order to become effective, teachers and students need to develop critical thinking skills. Students are encouraged for sharing knowledge, having debate and dialogue over the teaching and learning issues. Gone are the days when teachers' assumed responsibility was to teach a system of language to enable students to communicate well in the target language. If they want to prepare students for social, political, and economic transformation, then they should offer knowledge, debate, and dialogue to students (Giroux and Giroux, 2006).

Freira blends humanism of religions and criticality of Marx in his theory of critical pedagogy. Hindu and Buddhist cultures in the east had critical pedagogy in the Gurukul education system and this same was possibly raised as issue and theory in the western system of education in $20^{\text {th }}$ century.

Dr. A.S. Altekar says, "The Gurukul system which necessitated the stay of the student away from his home at the home of the teacher or in boarding house of established reputation, was one of the most important features of ancient Indian education." (Manikandaprabhu, 2016) 
Freire's critical pedagogy, as an alternative conception of education, is in accord with Marx's socialist principles. Changing social conditions create new forms of education for social relations, values, and practices. Socialist conditions require new modes of education. The materialist doctrine, that men are products of circumstances and upbringing, and that, therefore, changed men are products of other circumstances and changed upbringing, forgets that it is men who change circumstances and that it is essential to educate the educator himself.

In "The Pedagogy of the Oppressed" (1972), Paulo Freire criticized the "banking concept of education". He proposed for more interactive, dialogical, and participatory forms of pedagogy. With the spirit of Marxist revolutionary praxis, Freire developed a pedagogy of the oppressed that would produce revolutionary people, empowered to overthrow oppression and to create a more democratic and just social order.

The pedagogy of the oppressed is a task for radicals; it cannot be carried out by sectarians (Paulo Freire). Freirean pedagogy of the oppressed inspires for autonomy and emancipation. Freire argues that classical Marxism had not adequately developed the subjective and pedagogical dimension and that the oppressed must be educated so that they can perform their own self-emancipation.

McKernan (2013) writes that critical pedagogy is a movement involving relationships of teaching and learning so that students gain a critical self-consciousness and social awareness and take appropriate action against oppressive forces. This very concept is central to Freire's notion of "conscientization"; that is, the coming to personal critical consciousness.

Freire gives emphasis on "just, serious, humble, and generous relationships" for better educational practice (Freire, 1998). Such relationship is necessary to prepare the students as agents of change that will transform society (Fischman \& McLaren, 2005). It will increase consciousness which will, in turn, contribute to understanding of the society's shortcomings, 
which need to be transformed, and in Freire's words, "Critical understanding leads to critical action" (Freire, 1974) for the transformation of the society.

Critical pedagogy has visions for developing critical mind of the students with the aim of transforming the society. However, this teaching approach is being criticized for various reasons. One of the major criticisms is that it is mainly focusing on a macro level system critic than engaging in an action at a micro level in a classroom reality (McArthur, 2010).

Another weakness is that it is more engaged in critic than creating a "substantive vision" (Giroux in Breunig, 2005). Critical pedagogy, more than criticizing the existing system, criticizes for "having model towards which schools aspire". Moreover, it is criticized for being "...excessively abstract and too far removed from everyday life of school" (Breunig, 2005). Critical pedagogy has the following basic principles:

1. Education is a conversation between teacher and students. Students and their teacher pose problems and solve problems together.

2. Education broadens the student's view of reality with changing perception of the world.

3. Education is empowering the students with consciousness or "conscientization".

4. Education is transformative. Both teacher and students can acknowledge a change in perception.

5. Education is political. There are frequent issues of power and control in the classroom and also in the community.

Freire argues that, unless the learning facilitates a change in the student's perception of reality, learning has not occurred. Teachers facilitate the students to draw on their own realities to create new possibilities. Weiler (1989) remarks, "one of the most important pedagogical tenets for Freire was the need for teachers to respect the consciousness and culture of their students and to create the pedagogical situation in which students can 
articulate their understanding of the world". Freirean critical pedagogy presents five-step process in the problem posing model of education (Nixon Ponder, 1995):

1. Describe the content. The texts must originate from the students' concerns and experiences, which are significant in the students' daily lives.

2. Define the problem. Critical vocabulary and theories would be very useful here. It will be better to have one question at a time.

3. Personalize the problem. Student raises the problem from the text and related to his/her own experiences. Critical approach to the problem can be practised in pairs or groups and then in the whole class.

4. Discuss the problem. The students are engaged in identifying the reasons for the problem, to their own knowledge, and how the problem has affected their own lives. Teacher only facilitates the discussion without any personal imposition.

5. Discuss alternatives to the problem. Students are ready to face the challenge with alternative responses to the problem. Working in pairs or groups or as a classroom community, students construct a response to the problem. They build up confidence and ability to challenge and control their own realities.

In critical pedagogy, students take on the role of active learners (Crookes, 2010; Aliakbari \& Faraji, 2011). They are able to "learn, apply and process knowledge" (Koh, 2002). Thus, they learn, respond and raise questions, and become responsible for their own learning.

Students are engaged in posing questions and interacting and finding solutions even in English classrooms. They can develop a critical disposition towards reading the word and the world (Aliakbari \& Faraji, 2011). They can be inspired to be more reflective and productive readers (Van Duzer \& Florez, 1999; Wilson, 2014). In this way, they can benefit even in 
English Language and literature classrooms. They can challenge and face challenges of the world.

\section{Conclusion}

Critical pedagogy encourages teachers to consider their practice critically and complexities of the educational process through various viewpoints. Moreover, critical pedagogues share an end of academic success for each student, demonstrated in the preparation and experience of children to be active citizens in a fully democratic society. For critical pedagogues, the goal of education is for social transformation towards an entirely democratic society, where each comment is shared and heard in an equal way; one critically investigates oneself and one's society; and one acts upon decreasing social discriminations.

Criticality is certainly very indispensable in the present world. Many do not acquire information naturally and, moreover, they lack the ability and skills to analyze and think critically. Therefore, they are easily cheated in the market and in their community. To resist any kinds of cheating and find solutions to any problems in real life situations, critical thinking should be fostered in education system. Students should be encouraged for changes in their daily life. Transformation or change ensures development. Critical pedagogy helps to develop critical thinking skills which, in turn, help to solve economic, political, sociological, cultural issues in daily life. Teachers encourage students to voice their ideas and bring about transformation.

Teachers should go beyond the theoretical background of critical pedagogy. The theory should be implemented with action for all kinds of changes that the objectives of critical pedagogy designed for. Teachers must promote an integrated approach of theory and practice, or praxis in Freire's term, in the teaching process. Creating spaces for curriculum negotiation and critical dialogue provides students with opportunities to transform status quo 
discourses of schooling and education. It also allows for new ways of seeing and understanding oppressive ideologies and practices (e.g., racist stereotypes and discrimination) to emerge in order to resist social inequalities and to promote social justice. 


\section{References}

Aliakbari, M. \& Faraji, E. (2011). Basic Principles of Critical Pedagogy. 2nd International Conference on Humanities, Historical and Social Sciences IPEDR, 17, 78-85.

Akbari, R. (2008). Transforming lives: Introducing critical pedagogy into ELT classrooms. ELT journal, 62(3), 30-39.

Breunig, M. (2005). Turning Experiential Education and Critical Pedagogy Theory into Praxis. Journal of Experiential Education, 28(2), 106-122.

Breunig, M. (2008). Critical Pedagogy as Praxis. VDM Verlag.

Canagarajah, S. (2005). Critical pedagogy in L2 learning and teaching. In E. Hinkel (ed.), Handbook of research in second language teaching and learning. Mahwah, NJ: Lawrence Erlbaum Associates, 931-949.

Crookes, G. (2010). The practicality and relevance of second language critical pedagogy. Language Teaching, 43(3), 333-348.

Fischman, G. E. \& McLaren, P. (2005). Rethinking Critical Pedagogy and the Gramscian and Freirean Legacies: From Organic to Committed intellectuals or Critical Pedagogy, commitment, and Praxis. Cultural Studies, 5(4), 425-447.

Fisher, A. (2001). Critical thinking. Cambridge: Cambridge University Press.

Freire, P. (1970). Pedagogy of the oppressed. New York, NY: Continuum Books.

Freire, P. \& D. Macedo. (1987). Literacy: Reading the word and the world. London: Routledge.

Freire, P. (1974). Education for Critical Consciousness. New York: Continuum International Publishing Group.

Freire, P. (1986). The Politics of Education: Culture, Power, Liberation. Sout Hadley, MA: Bering \& Garvey Publishers. 
Freire, P. (1994). Pedagogy of Hope. Reliving Pedagogy of the Oppressed. New York: Continuum.

Freire, P. (1998). Pedagogy of Freedom: Ethics, Democracy, and Civic Courage. New York: Continuum International Publishing Group.

Freire, P. (2005). Teachers as cultural workers. Boulder, CO: West View Press.

Freire, P. (2014). Pedagogy of Hope. A and C Black. (reprint).

Giroux, H. (1983). Theory and Resistance in Education: Pedagogy for the Opposition. South Hadley: Bergin and Garvey.

Giroux, H. A. and Giroux, S. S. (2006). Challenging Neoliberaism's New Word Order: The Promise of Critical Pedagogy. Cultural studies, Critical methodologies. Sage Publications, 6 (1), $21-32$.

Gurubhaktananda, S. (2017). The Sandeepany Experience. Text 08. Sandeepany Sadhanalaya.

Kincheloe, J. (2007). Critical pedagogy and cognition: An introduction to a post formal educational psychology. Dordrecht, Netherlands: Springer.

Koh, A. (2002). Towards a critical pedagogy: Creating 'thinking schools' in Singapore. Journal of Curriculum Studies, 34 (3), 255264.

Manikandaprabhu, S. (2016). The Gurukul System of Education. Retreived from http://www.edubilla.com/blog/the-gurukul-system-of-education/

McArthur, J. (2010). Achieving Social Justice within and through Higher Education: Challenge for Critical Pedagogy. Teaching in Higher Education, 15(5), 493-504.

McLaren, P. (1988). Culture or canon? Critical pedagogy and the politics of literacy. Harvard Education Review. 58, 213 - 234.

McLaren, P. (2001). Che Guevara, Paulo Freire, and the Politics of Hope: Reclaiming Critical Pedagogy. Sage Publications. 1, $108-118$. 
McLaren, P. (2013). Critical Pedagogy: A Look at the Major Concepts. In A. Darder M, Baltodano; R. D. Torres (Eds.), Critical Pedagogy Reader (pp. 69-96). New York: Routledge Falmer.

McLaren, P. (2015). Life in Schools. Routledge.

Nixon Ponder, S. (1995). Using problem posing dialogue in adult literacy education: Teacher to teacher. Ohio, USA: Ohio Literacy Resource Center.

Pennycook, A. (1990). Critical Pedagogy and Second Language Education. System, 18/3, $303-314$

Shor, I. (1992). Empowering education. Critical teaching for social change. Chicago: The University of Chicago Press.

Shor, I. (1996). When students have power. Negotiating authority in a critical pedagogy. Chicago: The University of Chicago Press.

Shor, I. (1999). What is critical literacy? Journal of Pedagogy, Pluralism \& Practice, 1(4). Retrieved from www.lesley.edu/journals/jppp/4/shor.html

Swain, S. (2016). Educational Elements and Veda. $4{ }^{\text {th }}$ Chapter. Shodhganga.

Torres, C. A. \& Rexhep, J. (2011). British Journal of Sociology of Education, 32(5), 679-698.

Van Duzer, C., \& Florez, M.C. (1999). Critical literacy for adult English language learners. In National Center for ESL Literacy Education. Retrieved from http://www.cal.org/caela/esl_resources/digests/critlit.html

Weiler, K. (1989). Women's History and the History of Women Teachers. Journal of Education, Vol. 171, Number 3.

Wilson, B. (2014). Teach the how: Critical lenses and critical literacy. English Journal, 103 (4), 6875 . 